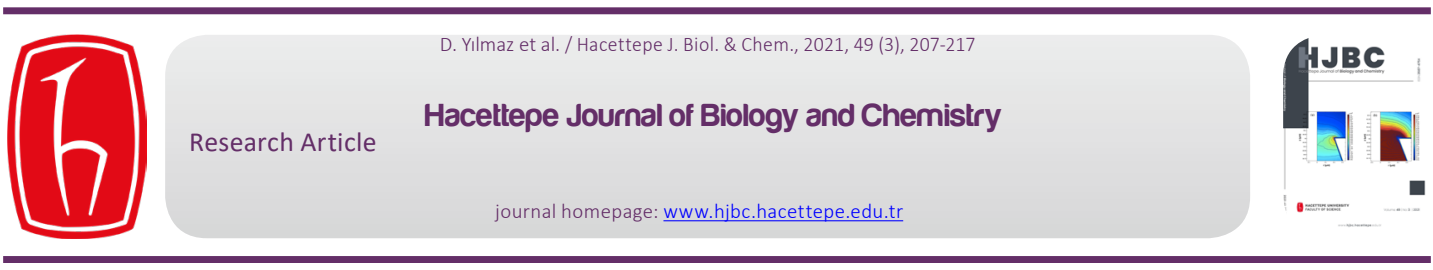

\title{
Effects of Asymmetric Nanopore Geometries on Nanoparticle Sensing Using Track-Etched Nanopore Membranes
}

\section{Asimetrik Nanopor Geometrilerinin İz-Aşındırıımış Nanopor Membranlar Kullanarak Nanoparçacık Algılamaya Etkilerinin Incelenmesi}

\author{
Dürdane Yılmaz ${ }^{1 \oplus}$, Dila Kaya ${ }^{\circledR}$, Kaan Keçeci $^{2 *}$ and Ali Dinler ${ }^{3 \odot}$ \\ ${ }^{1}$ Nanoscience and Nanoengineering Programme, Istanbul Medeniyet University, Istanbul, Turkey. \\ ${ }^{2}$ Department of Chemistry, Istanbul Medeniyet University, Istanbul, Turkey. \\ ${ }^{3}$ Department of Applied Mathematics, Istanbul Medeniyet University, Istanbul, Turkey.
}

\section{ABSTRACT}

R esistive pulse sensing, based on the Coulter Counter principle, is an important assay for sensing and separation pro$R_{\text {cesses to detect/discriminate several types of particles in various mediums. In such a set-up, attaining the signal from }}$ the smaller particles can be hard compared to larger particles. In this work, we focus on the critical role of pore shape on signal precision. We have simulated hourglass and cigar shaped nanopores to study the sensitivity for small particles. We have considered the translocation of $120 \mathrm{~nm}$ diameter particle by altering the surface charge as $-0.001 \mathrm{C} / \mathrm{m}^{2},-0.007 \mathrm{C} / \mathrm{m}^{2}$ and $-0.015 \mathrm{C} / \mathrm{m}^{2}$ under the applied potential between $-0.3 \mathrm{~V}$ and $-1 \mathrm{~V}$ with 0.1 increments. We have compared the signals in different concentration for identical-sized particles with varying surface charges. Comparison of pulse magnitudes and normalized current changes obtained from each pore shapes have shown that the cigar shaped pore yields more prominent signals for smaller sized particles than the hourglass pore. The results reveal that the hourglass shaped pore provides higher sensitivity than cigar shaped to discriminate the smaller particles and the hourglass pore might be preferable for nanopore sensor applications.

\section{Key Words}

Resistive-pulse sensing, nanopore sensing, nanoparticle sensing, COMSOL, finite element simulation.

\section{öz}

\begin{abstract}
Coulter Counter prensibine dayanan dirençli atış taraması, çeşitli ortamlardaki farklı partikül tiplerini tespit etmek / ayırt etmek için algılama ve ayırma işlemlerinde önemli bir tekniktir. Böyle bir düzenekte, daha küçük parçacıklardan sinyal elde etmek daha büyük parçacıklara kıyasla zor olabilir. Bu çalışmada, gözenek şeklinin sinyal hassasiyeti üzerindeki kritik rolüne odaklanılmıştır. Küçük parçacıkların hassasiyetini incelemek için kum saati ve puro şekilli nanogözenekler simüle edilmiştir. Yüzey yükünü $-0.31 \mathrm{C} / \mathrm{m}^{2},-0.007 \mathrm{C} / \mathrm{m}^{2}$ ve $-0.015 \mathrm{C} / \mathrm{m}^{2}$ olarak $-0.3 \mathrm{~V}$ ile $-1 \mathrm{~V}$ arasında $0,1^{\prime}$ lik artışlarla değiştirerek $120 \mathrm{~nm}$ çapındaki parçacığın gözenekten geçişi incelenmiştir. Değişken yüzey yüklerine sahip özdeş boyutlu parçacıklar için sinyaller farklı konsantrasyonlarda karşılaştırılmıştır. Her gözenek şeklinden elde edilen sinyal büyüklüklerinin ve normalize edilmiş akım değişikliklerinin karşılaştırılması, puro şeklindeki gözeneğin kum saati gözeneğine kıyasla daha küçük boyutlu parçacıklar için daha belirgin sinyaller verdiğini göstermiştir. Sonuçlar, kum saati şeklindeki gözeneğin, daha küçük parçacıkları ayırt etmek için puro şeklinden daha yüksek hassasiyet sağladığını ve kum saati gözeneğinin nanogözenek sensör uygulamaları için tercih edilebileceğini ortaya koymaktadır.
\end{abstract}

\section{Anahtar Kelimeler}

Nanopor sensör, nanoparçacık algılama, COMSOL, sonlu eleman simülasyonu. 


\section{INTRODUCTION}

Resistive pulse sensing (RPS) method which entails the use of nanopores has been widely implemented for many applications such as biomolecule detection (DNA, protein, virus) [1-3], nanoparticle characterization [4, 5], desalination [6] in various fields such as health/medicine [7], energy [8] and food engineering [9]. The system is based on the Coulter Counter principle [10]. The main point of this tool is the detection of a target element through analyzing the ionic current change formed by the translocated ions and/or particles. Acquired current change is then utilized as a detecting signal.

Sensitivity accuracy is a fundamental point to evaluate the qualification of the signal. Precision of the analysis, not only but significantly, depends on the pore geometry $[11,12]$, applied potential $[13,14]$ and surface charges $[15,16]$. It has been shown that the conical pores outperforms the cylindrical pores in sensing applications [17]. Other than the conical shape, other possible asymmetric pore shapes have also been investigated [18-21] and studies indicate that the distortion of the conical geometry to cigar and hourglass shapes may increase the sensing ability [22, 23].
The sensing capacity is directly related to the surface charges of the pore and the particle. The particle surface charge is particularly influence the signal generation during the particle translocation [13, 24]. Different types of synthetic and biological submicron particles in wide ranges of size and shape have been investigated $[25,26]$. Translocated particle blocks the ionic flow, which is known as the volume exclusion effect. Blocked ions (excluded ionic flow) reflected as a signal drop that provides knowledge to characterize the particle. Depending on the pore geometry, to obtain a stronger signal, it is necessary that there is a small gap between the pore and the particle [27]. Therefore, detection of the particles with low surface charge and small diameter is not easy compared with the detection of larger particles.

In this study, we aim to investigate effect of the nanopore geometry on signal precision for the small particle detection under variations of applied potential, particle surface charge and concentration. Simulations allow to compare the signals by keeping all other factors under control on perfectly shaped geometries. The cigar shape and hourglass shape pores are selected due to their a)

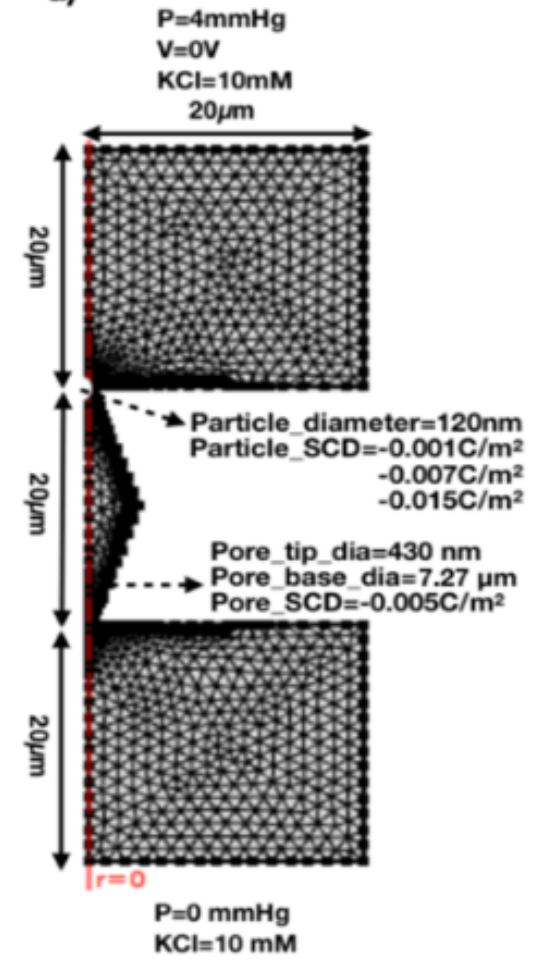

b)

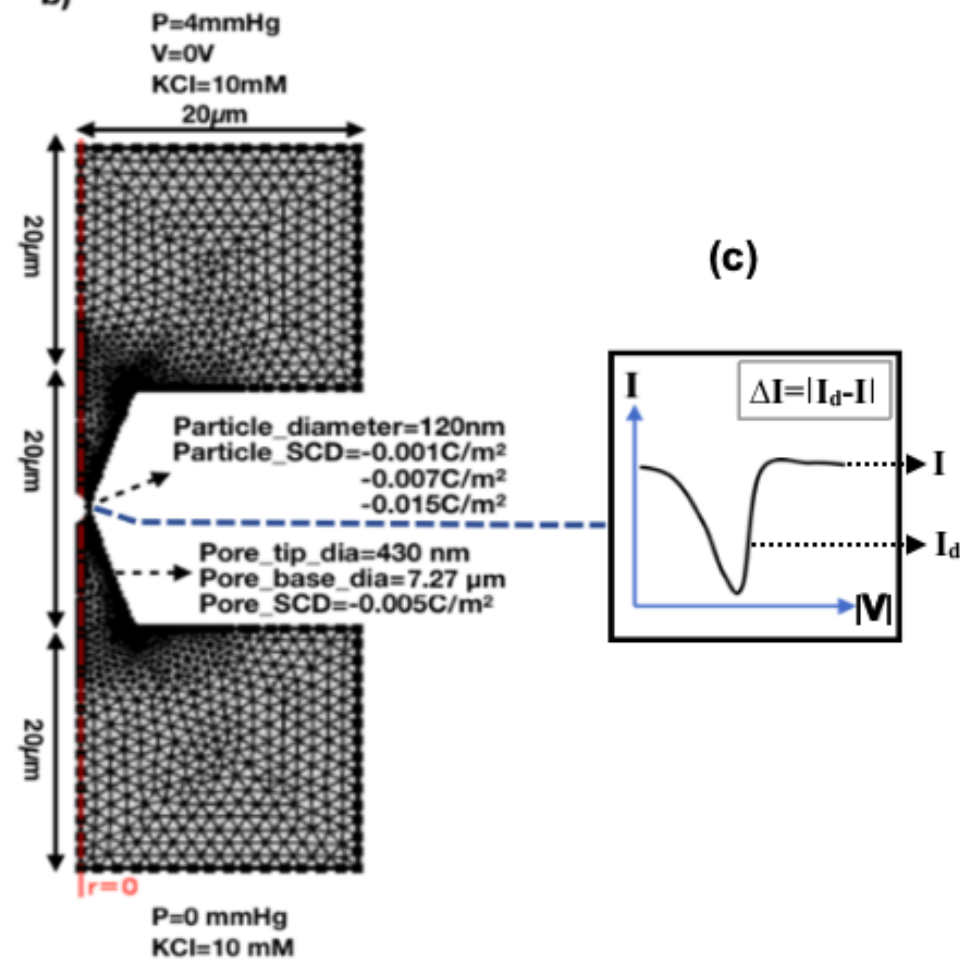

Figure 1. Mesh and boundary conditions of simulated pore geometries (a) cigar shaped nanopore, (b) hourglass shaped nanopore and (c) I- $|\mathrm{V}|$ signal due to the particle translocation. 
proven higher sensing potentials [28]. Obtained signal magnitudes and signal differences are evaluated in detail.

\section{MATERIALS and METHODS}

\section{Mathematical Model}

In this study, we investigate the two different nanopore geometries' efficiency for the detection of small diameter particles. As shown in Figure 1a, cigar shaped pore has two identical tips located at the upper and bottom entrances, respectively, while hourglass shaped pore has one tip zone placed in the middle of the membrane, Figure 1b.

Geometries are modelled as 2D axially symmetric half plane by using COMSOL Multiphysics v.4.4 software (COMSOL, Inc.). Parameters are set as following; the pore length is $20 \mu \mathrm{m}$, the pore tip diameter is $430 \mathrm{~nm}$ and the base diameter is $7.27 \mu \mathrm{m}$, the applied pressure is $4 \mathrm{mmHg}$, the voltage applied between $-0.3 \mathrm{~V}$ and $-1 \mathrm{~V}$ the ionic concentration is $10 \mathrm{mM}$ and the translocated particle diameter is $120 \mathrm{~nm}$ with varying surface charge densities of $-0.001 \mathrm{C} / \mathrm{m}^{2},-0.007 \mathrm{C} / \mathrm{m}^{2},-0.015 \mathrm{C} / \mathrm{m}^{2}$.
COMSOL Multiphysics coupled the Poison equation, the Nernst-Planck equation and the Navier-Stokes equation to simulate the models. The Poison equation, describes the electric potential association with the voltage and charge distributions, calculated according to the following formula:

$\nabla^{2} E=-\frac{\rho}{\varepsilon_{r} \varepsilon_{0}}=-\frac{\mathrm{Fa}}{\varepsilon_{r} \varepsilon_{0}} \sum_{i} z_{i} c_{i}^{\prime}$,

where $E, \rho, \varepsilon_{r}=80, \varepsilon_{0}=8.854 \times 10^{-12} \mathrm{~F} / \mathrm{m}$,

$\mathrm{Fa}=96485 \mathrm{C} / \mathrm{mol}$ are the electric potential, the electric charge density, the relative permittivity, the vacuum permittivity and the Faraday constant, respectively, with given values. $\boldsymbol{z}_{\boldsymbol{i}}$ and $\boldsymbol{c}_{\boldsymbol{i}}$ are the valence and concentration of the $i^{\text {th }}$ ionic species, respectively.

The Nernst-Planck equation is:

$\nabla \cdot\left(-D_{i} \nabla c_{i}-z_{i} \frac{D_{i}}{R T} \mathrm{Fa} \nabla E\right)=-\vec{u} \cdot \nabla c_{i}{ }^{\prime}$

where $D_{i}, c_{i}, R, T, \vec{u}$ are the diffusivity, the concentration of the $i^{\text {th }}$ ionic species, the gas constant, the absolute temperature and the velocity vector, respectively. The diffusion constant of potassium is given as $1.957 \times 10^{-9} \mathrm{~m}^{2} / \mathrm{s}$ and chlorine ions are set to $2.03 \times 10^{-9}$ $\mathrm{m}^{2} / \mathrm{s}$ [29]. $D_{i} / R T$ gives the mobility in the electric field (s mol/kg). Zero normal flux boundary condition is employed at all walls,

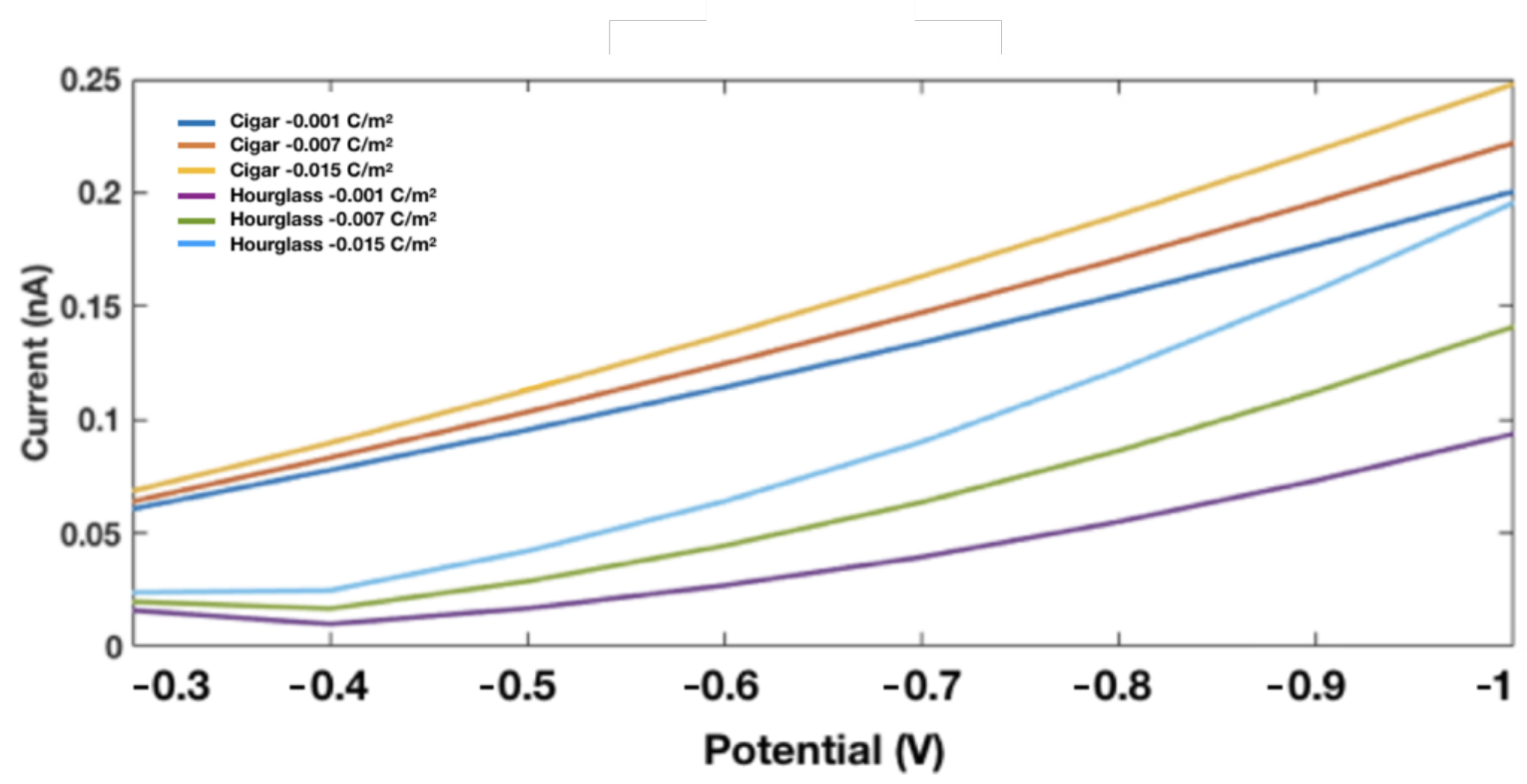

Figure 2. Signal amplitude $(\Delta \mathrm{I})$ values $120 \mathrm{~nm}$-diameter particle with varying surface charges obtained from the cigar and hourglass shaped pores. Dark blue-red-yellow lines indicate the signals from the cigar shaped pore for $-0.001 \mathrm{C} / \mathrm{m}^{2},-0.007 \mathrm{C} / \mathrm{m}^{2},-0.015 \mathrm{C} / \mathrm{m}^{2}$ surface charged particles, respectively. Purple-green-blue lines indicate the signals from the hourglass shaped pore for $-0.001 \mathrm{C} / \mathrm{m}^{2}$, $-0.007 \mathrm{C} / \mathrm{m}^{2},-0.015 \mathrm{C} / \mathrm{m}^{2}$ surface charged particles, respectively. 
$\mathbf{n} \cdot\left(-D_{i} \nabla c_{i}-z_{i} D_{i} /(R T) \mathrm{Fa} \nabla E\right)=0$, where $\mathbf{n}$ is the normal vector to the surface. The coupling of these two equations, Poison and Nernst-Planck, yields the ionic concentration and electric potential interactions.

The Navier-Stokes equation is:

$\eta \nabla^{2} \vec{u}-\nabla p-\mathrm{Fa} \sum_{i} z_{i} c_{i} \nabla E=0^{\prime}$

where $\eta$ is the deionized water viscosity and $p$ is the fluid pressure. Applied pressure is $4 \mathrm{mmHg}$. No-slip boundary condition is employed at all walls. To take the pressure and the electro-osmotic flow into account, the Navier-Stokes equation is coupled with the PoisonNernst-Planck equations. Simulations were computed in a laptop computer (Intel Core i5-2520M 1.6 GHz, 4 GB RAM). The electric field, electrolyte concentration and flow field were obtained in the half-plane. The model also considered the electro-osmotic flow and the formation of the electrical double layer at the pore walls.

\section{RESULTS and DISCUSSION}

\section{Effect of Pore Geometry on Detection Sensitivity for Small Particles}

When the particle diameter and the tip diameter are not comparable to each other, detecting the smaller particles becomes harder [30]. Previously, we showed that distorting the conical pore shape into the cigar or hourglass geometry can enhance the pore sensitivity and detection capability significantly [28]. In this study, we compare the small particle translocation through the cigar and hourglass shaped pores. It is known that [13], ionic current is directly proportional to the applied potential and the current rate with the applied potential should validate Ohm's law, since the nanopore setting resembles a circuit. Thus, to present the sensitivity accuracy, we analyzed the obtained signals by reading the current-potential (I-V) relation corresponding to Ohm's law (Figure 1(c)).

We considered the I-V curves of a negatively charged 120-nm diameter particle translocating through the cigar and hourglass shaped pores in $0.01 \mathrm{M} \mathrm{KCl}$ concentration under the applied potential ranging between -0.3 $\mathrm{V}$ and $-1 \mathrm{~V}$ with $0.1 \mathrm{~V}$ steps, shown in Figure 2. According to our simulations, applied voltages prior to -0.3 $\mathrm{V}$ did not yield meaningful signals, therefore $-0.3 \mathrm{~V}$ was chosen as the threshold potential. In Figure 2, the I-V relation consistency can be observed where increasing current is accompanied by increasing potential.

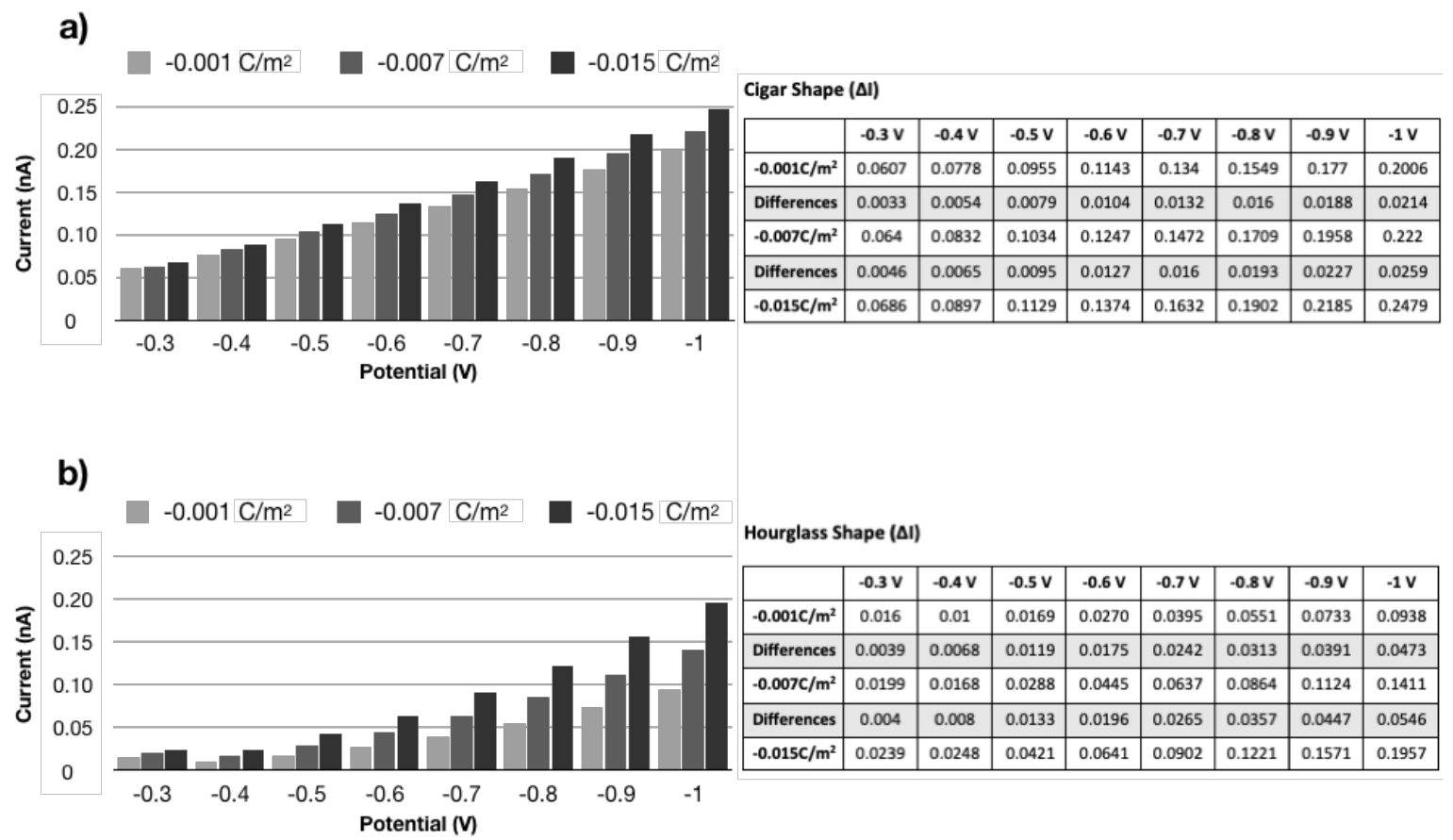

Figure 3. Signal amplitude $(\Delta \mathrm{I})$ values are obtained for $120 \mathrm{~nm}$-diameter particle associated with varying particle surface charge densities for (a) cigar shaped and (b) hourglass shaped pores. Light grey, grey and black bars demonstrate the $-0.001 \mathrm{C} / \mathrm{m}^{2},-0.007 \mathrm{C} /$ $\mathrm{m}^{2}$ and $-0.015 \mathrm{C} / \mathrm{m}^{2}$ surface charges, respectively. 

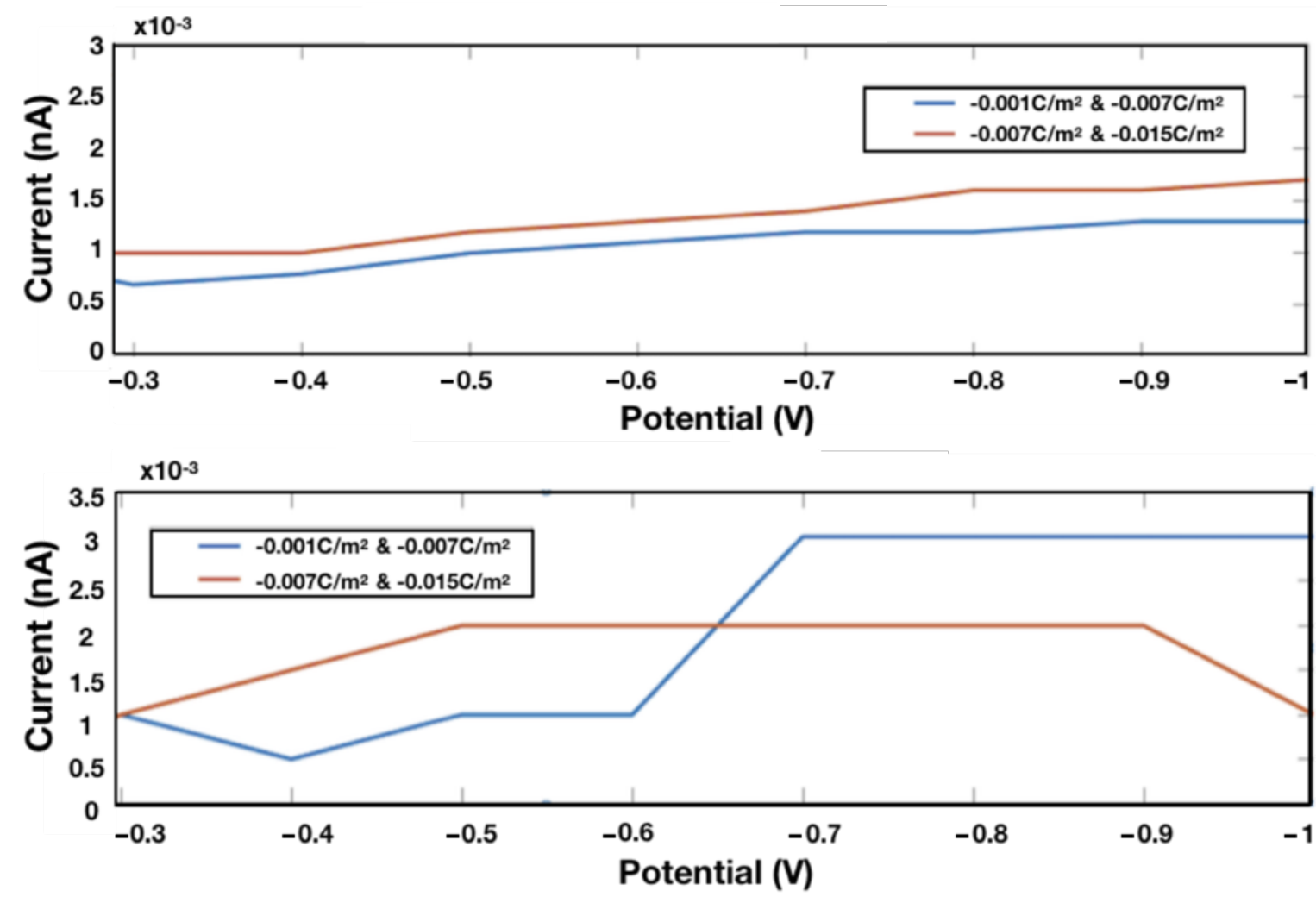

Figure 4. Current signal differences demonstration, separately, obtained from the (a) cigar shaped pore and (b) hourglass shaped pore corresponding to the particle surface charge variations. Blue lines represent the difference in current at $-0.001 \mathrm{C} / \mathrm{m}^{2}$ and $-0.007 \mathrm{C} / \mathrm{m}^{2}$ and red lines represent the difference in current at $-0.007 \mathrm{C} / \mathrm{m}^{2}$ and $-0.015 \mathrm{C} / \mathrm{m}^{2}$.

Sensitivity analysis is the main purpose of this study. We determined the more sensitive geometry to the small particle via the comparison of both the pulse magnitudes and the normalized current changes in each geometry. Signals were obtained from the each pore geometry on the following conditions: $120-\mathrm{nm}$ particle with $-0.001 \mathrm{C} / \mathrm{m}^{2},-0.007 \mathrm{C} / \mathrm{m}^{2},-0.015 \mathrm{C} / \mathrm{m}^{2}$ surface charge under the applied potential between $-0.3 \mathrm{~V}$ and $-1 \mathrm{~V}$ were tested.

Figure 2 demonstrates the obtained signal amplitudes $(\Delta \mathrm{I})$ that increase with the increasing potential for different surface charges in both geometries. Figure 2 shows that the cigar shaped pore yields a higher current for small sized particles in either cases of increasing potential and increasing surface charges than the hourglass pore. $\Delta I$ is defined as $\left|I_{d}-1\right|$ (Figure $1 \mathrm{c}$ ). $I_{d}$ represents the current drop due to the existence of the particle. It is the off-current state of the ionic flow since the particle occupies the sensing zone (tip) of the pore and causes a decrease in the ionic current. I is the on- current state of the ionic flow, also called as the base line current (i.e. initial ionic current), demonstrates the unoccupied situation of the sensing zone (tip) of the pore by the particle. The $\Delta \mathrm{l}$ quantities in Figure 2 can be identified from the bar charts in Figure $3 a-b$. When we assess the pore sensitivity via the signal magnitude difference, the signal variations obtained from the hourglass pore have been found to be higher than the cigar shaped pore. Large distinctions between the signal magnitudes imply a valuable particle discrimination feature. Therefore, we can conclude from Figure 3 that the hourglass pore has higher sensitivity to detect individual small particles than cigar shape.

When we measure the signal differences with respect to the particle surface charge as given in Figure 4, the hourglass shape again more efficient because of the distinct current changes. Here, we evaluate the signal variations with respect to the particle surface charge to exhibit the surface charge effects on the generated signals. We calculate the current differences between 


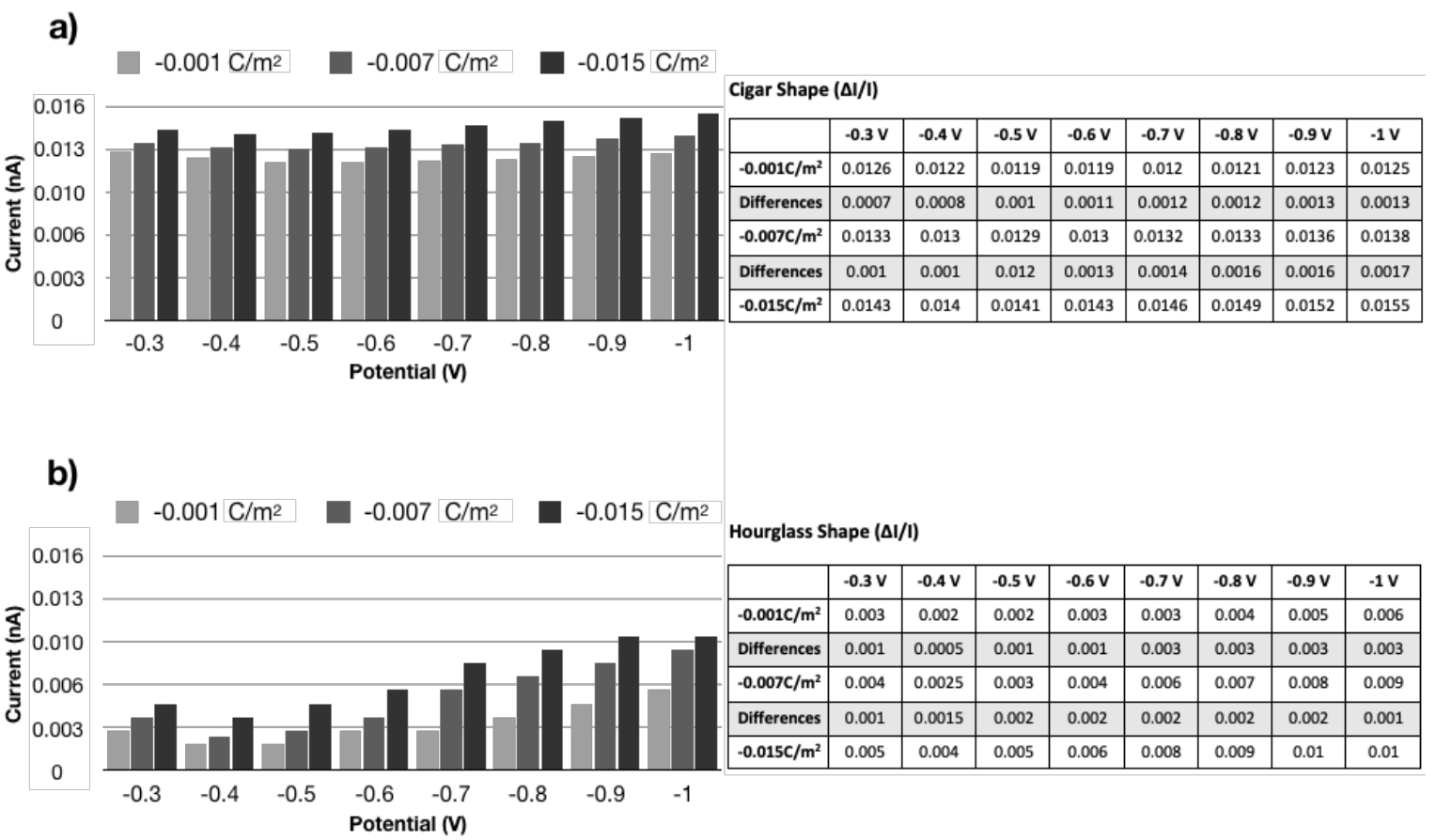

Figure 5. Bar charts and normalized current changes $(\Delta \mathrm{l} / \mathrm{l})$ for the signal differences obtained from the (a) cigar shaped pore and (b) hourglass shaped pore corresponding to the particle surface charge variations. Light grey, grey and black bars demonstrate the -0.001 $\mathrm{C} / \mathrm{m}^{2},-0.007 \mathrm{C} / \mathrm{m}^{2}$ and $-0.015 \mathrm{C} / \mathrm{m}^{2}$ surface charges, respectively.

the signals produced for different surface charges. As shown in Figure 4a, for cigar shaped pore, the results demonstrate a monotonic increasing rate between signal differences for varying surface charges at increasing potential. The hourglass pore generates apparent distinct responds to the charge variations (Figure $4 \mathrm{~b}$ ) and the obtained current changes are significantly higher as shown in Figure $5 b$. As can be observe from Figure $4 \mathrm{~b}$, difference in current at $-0.001 \mathrm{C} / \mathrm{m}^{2}$ and $-0.007 \mathrm{C} /$ $\mathrm{m}^{2}$ shows unstable, up-down behavior until $0.6 \mathrm{~V}$. From that point on, the magnitude differences in current at $-0.001 \mathrm{C} / \mathrm{m}^{2}$ and $-0.007 \mathrm{C} / \mathrm{m}^{2}$ first linearly increase and then stabilized. We can deduce that the effects of the higher potential and lower potential are approximately same for the differences between the high surface charge cases, i.e. $-0.007 \mathrm{C} / \mathrm{m}^{2}$ and $-0.015 \mathrm{C} / \mathrm{m}^{2}$. The effects are more prominent in Figure $5 \mathrm{a}-\mathrm{b}$ by bar charts with normalized current changes $\left(\Delta \mathrm{I} / \mathrm{I}=\left(\left|\mathrm{I}_{\mathrm{d}}-\mathrm{I}\right| / \mathrm{I}\right)\right.$ that provides modulation of the current to eliminate the redundancies.

\section{Comparison of Pore Geometries for Detecting Charge Variations of Small Particles}

Surface properties of nanoparticles are key to understand their state/behavior in the electrolyte medium. One of these parameters is the surface charge density of a particle which plays an important role in the detection [31]. Particle surface charge manifests itself in the signal pulse and it is effective on the signal shape. This section investigates the translocation of small $(120 \mathrm{~nm}$ diameter) particle under fixed applied potential by setting the particle surface charges as $-0.015 \mathrm{C} / \mathrm{m}^{2},-0.007$ $\mathrm{c} / \mathrm{m}^{2}$ and $-0.001 \mathrm{C} / \mathrm{m}^{2}$, respectively. Then it compares the sensitivities of the cigar shaped and hourglass shaped pores by measuring the current magnitudes.

Signals attained from each pore geometries show increasing current tendency corresponding to increasing particle surface charges and potentials as exhibited in Figure 2. Evaluation of the charge alteration has shown that the particle surface charge variation is also an effective factor on the current. 


\section{$-0.001 \mathrm{C} / \mathrm{m}^{2} \square-0.007 \mathrm{C} / \mathrm{m}^{2} \square-0.015 \mathrm{C} / \mathrm{m}^{2}$}

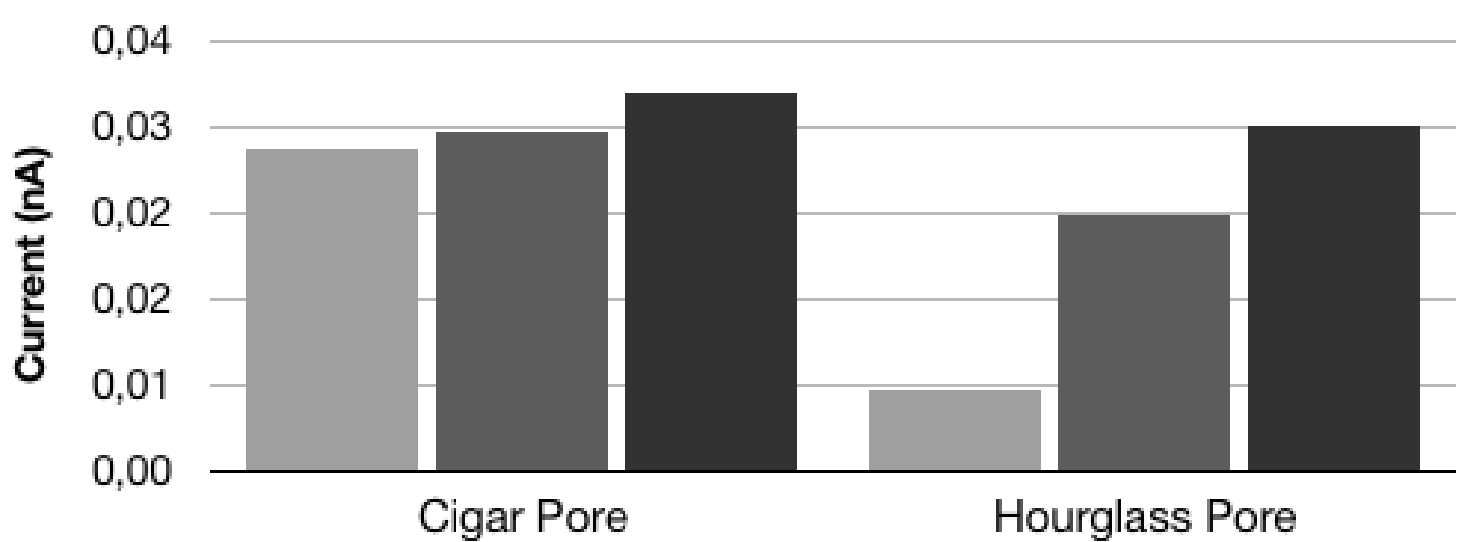

Figure 6. Signal amplitudes $(\Delta \mathrm{I})$ are obtained for 120-nm-diameter particle associated with varying particle surface charge densities. Light grey, grey and black blocks demonstrate the $-0.001 \mathrm{C} / \mathrm{m}^{2},-0.007 \mathrm{C} / \mathrm{m}^{2}$ and $-0.015 \mathrm{C} / \mathrm{m}^{2}$ surface charges, respectively.

Figure 6 shows the signal amplitudes $(\Delta \mathrm{I})$ according to the surface charge alteration. As can be observed from the bar chart comparison of pulse magnitudes, the cigar pore provides higher pulses for all surface charges than the hourglass pore. Cigar shaped pore's strong signal magnitudes can be attributed to its two narrow sensing zones, which are considered as a whole signal in this work. When an evaluation and comparison are made according to the charge values, the cigar pore is found to generate more precise signals in detecting small particles with $-0.001 \mathrm{C} / \mathrm{m}^{2}$ surface charge. However, the hourglass pore produces severely weak current magnitude for the same low surface charge. On the other hand, there is no significant distinction between $\Delta \mathrm{l}$ values obtained from both geometries for the high surface charge value of $-0.015 \mathrm{C} / \mathrm{m}^{2}$.

The cigar pore supplies significantly high current signal magnitudes for all charge conditions of a particle and this qualification makes this geometry utilizable to detect the small particles, but differences between the signals produced by this geometry are inadequate to separate them. Despite the low signal responds to the low charge values, hourglass pore attains higher sensitivity to distinct separation owing to the increasing signal magnitudes between different surface charges In summary, the hourglass pore gives a more sensitive response to the surface charge variations than cigar shape and performs better in charge discrimination of small particles.

\section{Effects of Electrolyte Concentration and Electric Field Strength Distributions on Small Particle Detection}

We have investigated the signals corresponding to three different electrolyte concentration, $10 \mathrm{mM}, 100$ $\mathrm{mM}, 1000 \mathrm{mM}$, for 120-nm particles with surface charges of $-0.001 \mathrm{C} / \mathrm{m}^{2},-0.007 \mathrm{C} / \mathrm{m}^{2}$ and $-0.015 \mathrm{C} / \mathrm{m}^{2}$. As can be seen in Figure 7, according to the increased current signal values one can interpret that the increased counterions on the particle cause intense concentration around the narrow region of the pore and cause higher signal generation. Acquired signals from the cigar shaped pore exhibit increasing tendency for higher concentration and fixed particle surface charge values. However, it does not produce satisfying distinctive signals for fixed concentration and different particle surface charge states.

Similar to the cigar shaped pore, signals obtained from the hourglass pore tend to increase with the increased concentration and does not show clear distinction corresponding to the charge variation under fixed electrolyte concentration. Yet, by increasing the concentration from $10 \mathrm{mM}$ to $1000 \mathrm{mM}$, even the magnitudes exhibit upward trend, signal differences become almost identical. We can infer from these outcomes that while the small particle sensing is hard, cigar shaped pore is more effective for the detection of small particles by producing signals with higher magnitudes than hourglass pore. Comparison of signal magnitudes between the cigar and hourglass pores shows the cigar shaped pore generates higher signals at low and medium con- 


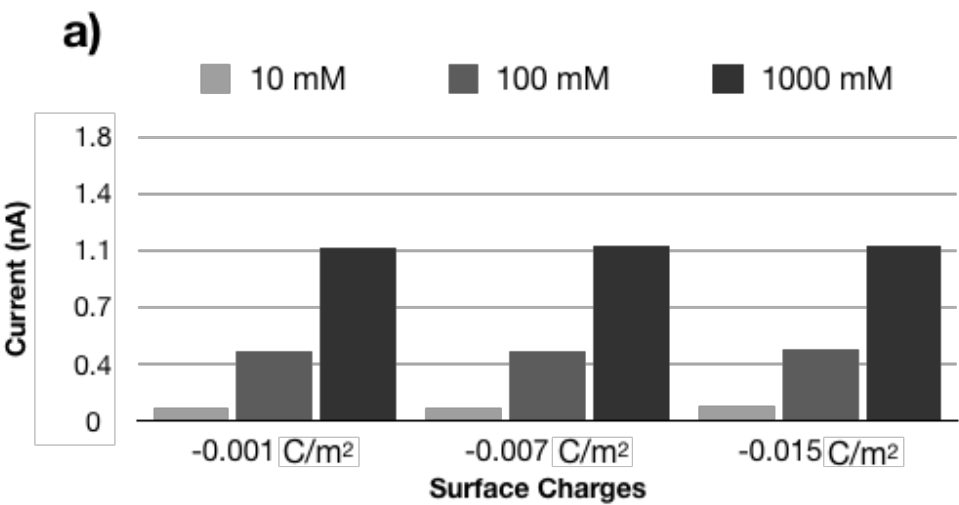

b)

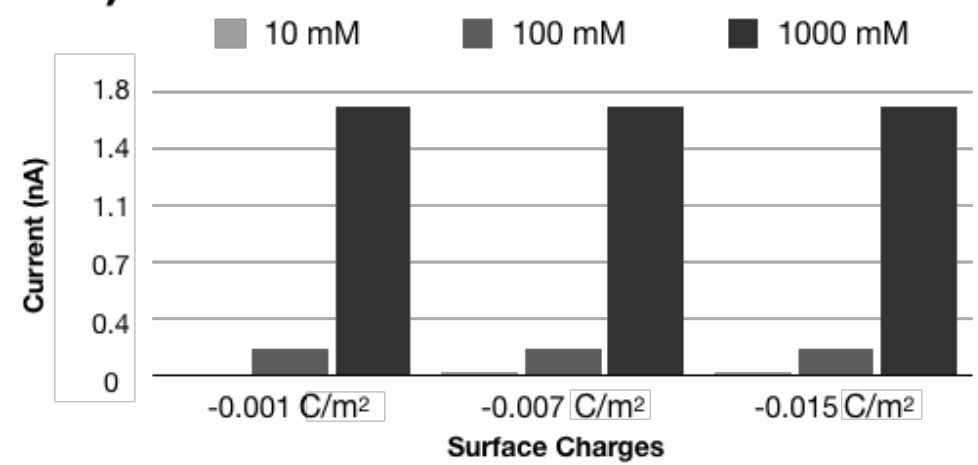

\section{Cigar Shape}

\begin{tabular}{|c|c|c|c|}
\hline & $10 \mathrm{mM}$ & $100 \mathrm{mM}$ & $1000 \mathrm{mM}$ \\
\hline$-0.001 \mathrm{C} / \mathrm{m}^{2}$ & 0.078 & 0.44 & 1.104 \\
\hline Differences & 0.005 & 0.008 & 0.006 \\
\hline$-0.007 \mathrm{C} / \mathrm{m}^{2}$ & 0.083 & 0.448 & 1.11 \\
\hline Differences & 0.007 & 0.009 & 0.008 \\
\hline$-0.015 \mathrm{C} / \mathrm{m}^{2}$ & 0.09 & 0.457 & 1.118 \\
\hline
\end{tabular}

Hourglass Shape

\begin{tabular}{|c|c|c|c|}
\hline & $10 \mathrm{mM}$ & $100 \mathrm{mM}$ & $1000 \mathrm{mM}$ \\
\hline$-0.001 \mathrm{C} / \mathrm{m}^{2}$ & 0.014 & 0.168 & 1.704 \\
\hline Differences & 0.006 & 0.005 & 0.004 \\
\hline$-0.007 \mathrm{C} / \mathrm{m}^{2}$ & 0.02 & 0.173 & 1.708 \\
\hline Differences & 0.007 & 0.004 & 0.004 \\
\hline$-0.015 \mathrm{C} / \mathrm{m}^{2}$ & 0.027 & 0.177 & 1.712 \\
\hline
\end{tabular}

Figure 7. Concentration distribution charts of a) cigar pore and b) hourglass pore according to concentration and particle surface charge variations. Light grey, grey, black blocks corresponds to $10 \mathrm{mM}, 100 \mathrm{mM}$ and $1000 \mathrm{mM} \mathrm{KCl}$ concentration, respectively.

centrations. Although the hourglass pore produces high signal in $1000 \mathrm{mM}$, according to the signal differences cigar pore exhibits better result.

According to the above investigations (Figure 2, Figure 4, Figure 6), it is concluded the cigar shaped pore can produce higher signals for the small particle detection but cannot provide good discrimination between particles. On the other hand here (Figure 7) it is shown that the cigar shaped pore is better than hourglass pore in terms of detection according to the concentration analysis with high signal magnitudes and signal distinctions.

The electric field is the gradient of the electric potential (electrophoresis effect) which drives the particle to move through the pore. It has been shown that the nanoparticles will always pass the nanopore if externally applied electric field is sufficiently high [32]. Also relation between the pore shape and electric field have reported as higher electric field strength and a wider capture zone were observed at the nanopore tip as cone angle was increased [11].

The electric fields for both geometries were plotted and compared to determine the electric field strength distributions under low and high applied potentials. It was found that for both pore shapes, electric field magnitude reaches its maximum around the tip corners (Figure 8). Electric field magnitude of the hourglass pore was measured as $\sim 5.18 \times 10^{6} \mathrm{~V} / \mathrm{m}$ at the tip corner and cigar pore's electric field strengths were around $6.1 \times 10^{6} \mathrm{~V} / \mathrm{m}$ and $6.64 \times 10^{6} \mathrm{~V} / \mathrm{m}$ at the upper and lower tip corners, respectively, which were higher than hourglass pore under the relatively low applied potential of $-0.3 \mathrm{~V}$.

Contour lines show that electric field is more intense at the tip of the cigar pore compared to hourglass pore. Electric field strength is measured as $\sim 4.36 \times 10^{6} \mathrm{~V} / \mathrm{m}$, $\sim 4.32 \times 10^{6} \mathrm{~V} / \mathrm{m}$ and $\sim 4.65 \times 10^{6} \mathrm{~V} / \mathrm{m}$ for the hourglass, the upper and the lower tips of the cigar pore, respectively, 

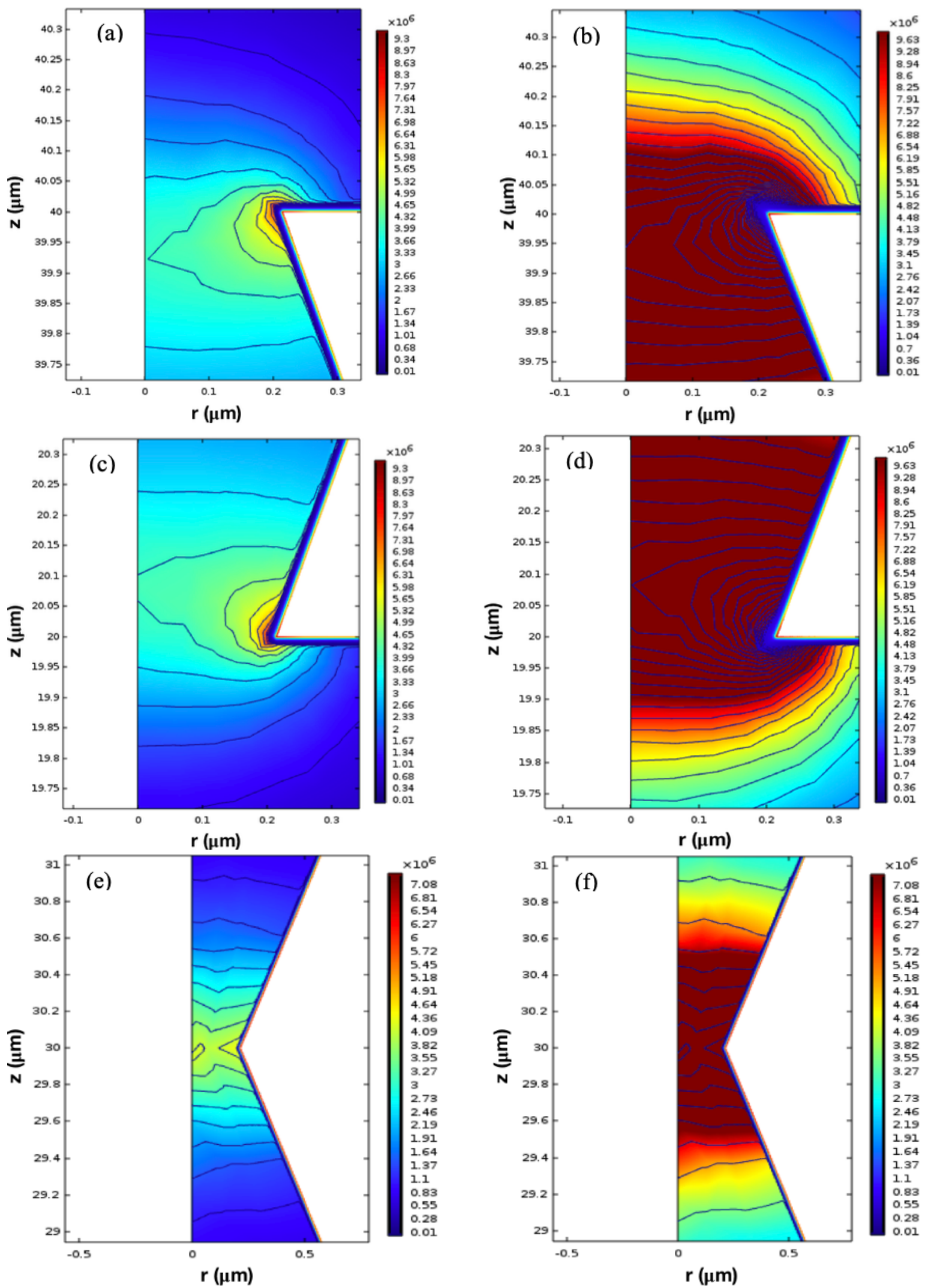

Figure 8. Electric field strength distributions around (a-b) the upper tip, (c-d) lower tip of the cigar pore and (e-f) tip of the hourglass pore with $-0.005 \mathrm{C} / \mathrm{m}^{2}$ membrane surface charge density under the applied potential $-0.3 \vee(a-c-e)$ and $-1 \vee(b-d-f)$. 
$0.03 \mu \mathrm{m}$ away in the radial direction from the tip corner If the capture zones around the upper tip of the cigar pore and around the tip of hourglass pore are compared, capture zones found to be almost same while lower tip of the cigar pore has a somewhat higher electric field strength. Under high potential values, cigar shaped pore outperformed the hourglass pore with $\sim 9.63 \times 10^{6}$ $\mathrm{V} / \mathrm{m}$ measured strength from both tips where hourglass yields around $7.08 \times 10^{6}$. This finding also clarifies how the cigar pore produces higher signal magnitudes than hourglass pore.

\section{Conclusion}

In the present study we ran simulations to consider the effects of pore geometry on smaller particle detection and discrimination by comparing hourglass and cigar shaped pores. The results showed that the pore geometry had profound effects on the pulse magnitude and sensitivity capability. The study summarized the best pore shapes for small particles for applications of charge discriminations under various conditions of applied potential, particle surface charge and electrolyte concentration.

When the applied potential was considered, it was observed that the current lines displayed an increasing tendency for all cases with the increasing potential. Thus, we conclude that in order to enhance the small particle detection precision, applying a higher potential is appropriate.

Investigation of pore sensitivity to specify the efficient geometry offered two options depending on the purpose: detection of size or charge. The obtained signals showed that the pulse magnitudes were significantly different depending on the pore geometry. The cigar pore outperformed hourglass pore by generating higher signal magnitudes in detection of small particles regardless of its charge. On the other hand, the hourglass pore produced more distinctive signals in the case of surface charge variation by yielding stronger variations in current magnitude. Furthermore, our simulations in reference to the concentration variations with different surface charged particles showed that the cigar shaped pore is better than hourglass pore with high signal magnitudes and signal distinctions in particle detection. However, for the discrimination, concentration analysis cannot provide an option between two geometries.
The outcomes of this work can be summarized as follows: the cigar pore generates higher signal magnitudes than hourglass in detection, which implies that the cigar shape is more efficient to detect small particles. On the other hand, hourglass pore is more sensitive to particle size variation which suggests that the hourglass shape is better for discriminating/classifying in the existence of small particles.

\section{Author Contribution}

A.D. and K.K. conceived the original idea and supervised the project. D.Y. and D.K. designed the simulations and setup mathematical model. D.Y. performed the simulations. All authors contributed to the manuscript writing.

\section{Acknowledgements}

D.Y. is supported by the Council of Higher Education (YÖK) of Turkey under the 100/2000 Doctoral Scholarship Program.

\section{References}

1. K. Liu, C. Pan, A. Kuhn, A.P. Nievergelt, G.E. Fantner, O. Milenkovic, Detecting topological variations of DNA at single-molecule level, Nat. Commun., 10 (2019) 3.

2. L.T. Sexton, L.P. Horne, S.A. Sherrill, G.W. Bishop, L.A. Baker, C.R. Martin, Resistive-pulse studies of proteins and protein/ antibody complexes using a conical nanotube sensor, J. Amer. Chem. Soc., 43 (2007) 13144-52.

3. A. Darvish, J.S. Lee, B. Peng, J. Saharia, R. Venkat Kalyana Sundaram, G. Goyal, Mechanical characterization of HIV1 with a solidstate nanopore sensor, Electrophoresis, 2018.

4. S. Lee, Y. Zhang, H.S. White, C.C. Harrell, C.R. Martin, Electrophoretic capture and detection of nanoparticles at the opening of a membrane pore using scanning electrochemical microscopy, Anal. Chem., 76 (2004) 610815.

5. G. Goyal, K.J. Freedman, M.J. Kim, Gold nanoparticle translocation dynamics and electrical detection of single particle diffusion using solid-state nanopores, Anal. Chem., 85 (2013) 8180-87.

6. C.C. Lai, C.J. Chang, Y.S. Huang, W.C. Chang, F.G. Tseng, Y.L. Chueh, Desalination of saline water by nanochannel arrays through manipulation of electrical double layer, Nano energy, 12 (2015) 394-400.

7. T. Hoenen, A. Groseth, K. Rosenke, R. J. Fischer, A. Hoenen, S.D. Judson, Nanopore sequencing as a rapidly deployable Ebola outbreak tool, Emer. Infect. Diseases, 22 (2016) 331.

8. A. Siria, P. Poncharal, A. L. Biance, R. Fulcrand, X. Blase, S.T. Purcell, Giant osmotic energy conversion measured in a single transmembrane boron nitride nanotube, Nature, 494 (2013) 455.

9. M.X. Quintanilla-Carvajal, B.H. Camacho-Díaz, L.S. Meraz-Torres, J.J. Chanona-Pérez, L. Alamilla-Beltrán, A. Jimenéz-Aparicio, Nanoencapsulation: a new trend in food engineering processing, Food Engineer. Rev., 2 (2010) 39-50. 
10. W.H. Coulter, Means for counting particles suspended in a fluid.: US Patent 2,656,508; 1953.

11. D. Kaya, A. Dinler, N. San, K. Kececi, Effect of Pore Geometry on Resistive-Pulse Sensing of DNA Using Track-Etched PET Nanopore Membrane, Electrochimica Acta, 202 (2016) 157 65.

12. K.P. Singh, M. Kumar, Effect of gate length and dielectric thickness on ion and fluid transport in a fluidic nanochannel, Lab on a Chip, 12 (2012) 1332-9.

13. W.J. Lan, C. Kubeil, J.W. Xiong, A. Bund, H.S. White, Effect of Surface Charge on the Resistive Pulse Waveshape during Particle Translocation through Glass Nanopores, J. Physic. Chem.C., 118 (2014) 2726-34

14. E. Weatherall, G.R. Willmott, Conductive and Biphasic Pulses in Tunable Resistive Pulse Sensing, J. Physic. Chem. B., 119 (2015) 5328-35.

15. Y. Qiu, C.Y. Lin, P. Hinkle, T.S. Plett, C. Yang, J.V. Chacko, Highly Charged Particles Cause a Larger Current Blockage in Micropores Compared to Neutral Particles, ACS Nano, 10 (2016) 8413-22.

16. J. Menestrina, C. Yang, M. Schiel, I. Vlassiouk, Z.S. Siwy, Charged particles modulate local ionic concentrations and cause formation of positive peaks in resistive-pulse-based detection, J. Phys. Chem. C., 118 (2014) 2391-8.

17. J. Cervera, B. Schiedt, R. Neumann, S. Mafé, P. Ramírez, Ionic conduction, rectification, and selectivity in single conical nanopores, J. Chem. Phys., 124 (2006) 104706.

18. D. Gillespie, D. Boda, Y. He, P. Apel, Z.S. Siwy, Synthetic nanopores as a test case for ion channel theories: the anomalous mole fraction effect without single filing, Biophys. J., 95 (2008) 609-19.

19. Z. Siwy, P. Apel, D. Dobrev, R. Neumann, R. Spohr, C. Trautmann, Ion transport through asymmetric nanopores prepared by ion track etching, Nucl. Instrum. Meth. B, 208 (2003) 143-148.

20. H. Zhang, X. Hou, Z. Yang, D. Yan, L. Li, Y. Tian, Bio-inspired smart single asymmetric hourglass nanochannels for continuous shape and ion transport control, Small, 11 (2015) 786-91.

21. P.Y. Apel, I.V. Blonskaya, S.N. Dmitriev, O.L. Orelovitch, A. Presz, B. A. Sartowska, Fabrication of nanopores in polymer foils with surfactant-controlled longitudinal profiles, Nanotechnology, 18 (2007) 305302.
22. P. Ramírez, P.Y. Apel, J. Cervera, S. Mafé, Pore structure and function of synthetic nanopores with fixed charges: tip shape and rectification properties, Nanotechnology, 19 (2008) 315707.

23. F.M. Gilles, M. Tagliazucchi, O. Azzaroni, I. Szleifer, Ionic Conductance of Polyelectrolyte-Modified Nanochannels: Nanoconfinement Effects on the Coupled Protonation Equilibria of Polyprotic Brushes, J. Phys. Chem. C., 120 (2016) 4789-98.

24. K.K. Chen, L. Shan, S.Y. He, G.Q. Hu, Y.G. Meng, Y. Tian, Biphasic Resistive Pulses and Ion Concentration Modulation during Particle Translocation through Cylindrical Nanopores, J. Phys. Chem. C, 119 (2015) 8329-35.

25. M. Firnkes, D. Pedone, J. Knezevic, M. Döblinger, U. Rant, Electrically facilitated translocations of proteins through silicon nitride nanopores: conjoint and competitive action of diffusion, electrophoresis, and electroosmosis, Nano Lett., 10 (2010) 2162-7.

26. S. Cabello-Aguilar, A.A. Chaay, M. Bechelany, C. PochatBohatier, E. Balanzat, J.M. Janot, Dynamics of polymer nanoparticles through a single artificial nanopore with a high-aspect-ratio, Soft Matter., 10 (2014) 8413-9.

27. K.E. Venta, M.B. Zanjani, X. Ye, G. Danda, C.B. Murray, J.R. Lukes, Gold nanorod translocations and charge measurement through solid-state nanopores, Nano Lett., 14 (2014) 5358-64.

28. D. Yilmaz, D. Kaya, K. Keçeci, A. Dinler, Effects of Nanopore Shape in Resistive-Pulse Sensing for Particle Discrimination (Submitted).

29. Y. Youn, S. Han, Investigation of field effects in a solid-state nanopore transistor, Phys. Chem. Chem. Phys., 17 (2015) 27806-11.

30. R. Vogel, G. Willmott, D. Kozak, G.S. Roberts, W. Anderson, L. Groenewegen, Quantitative sizing of nano/microparticles with a tunable elastomeric pore sensor, Anal. Chem., 83 (2011) 3499-506.

31. J. Jiang, G. Oberdörster, P. Biswas, Characterization of size, surface charge, and agglomeration state of nanoparticle dispersions for toxicological studies, J. Nanopart. Res., 11 (2009) 77-89.

32. S. Movahed S, D. Li, Electrokinetic motion of a rectangular nanoparticle in a nanochannel, J. Nanopart. Res., 14 (2012) 1032. 